\title{
STUDI LITERATUR PENTINGNYA PENERAPAN PENDIDIKAN KARAKTER BAGI PENDIDIKAN FORMAL SEKOLAH MENENGAH PERTAMA
}

\author{
Muhammad fiky mayshandy ${ }^{1 *}$ \\ ${ }^{1)}$ Pendidikan IPA/Pendidikan MIPA/FKIP,Universitas Jember, Indonesia \\ E-mail: fikymaysandy@gmail.com
}

\begin{abstract}
Character education of junior high schools in Indonesia is arguably less preferred. In fact, it only becomes limited to discourse in formal education. This article discusses the importance of character education in formal education. Starting from looking example of applications in China. Then, the business continued its application in formal junior high school education. These efforts include the establishment of character education as one of the reasons why the important of character building for student capital to mature.
\end{abstract}

Keywords: character education, design

\begin{abstract}
Abstrak
Pendidikan karakter sekolah menengah pertama di Indonesia bisa dibilang kurang diutamakan. Bahkan hanya menjadi sebatas wacana di pendidikan formal. Artikel ini membahas tentang pentingnya Pendidikan karakter di dalam Pendidikan formal. Dimulai dari melihat contoh penerapan pendidikan karakter di negara Cina. Kemudian, dilanjutkan usaha penerapannya di Pendidikan formal Sekolah Menengah Pertama. Usaha tersebut antara lain penetapan Pendidikan karakter sebagai salah satu tujuan mengapa pentingnya pembentukan karakter sebagai modal siswa menuju dewasa.
\end{abstract}

Kata kunci: Pendidikan karakter, perancangan

\section{PENDAhuluan}

Pendidikan merupakan upaya yang terencana dalam proses pembimbingan dan pembelajaran bagi individu agar berkembang dan tumbuh menjadi manusia yang mandiri, bertanggungjawab, hidup bersosial, berilmu, dan kreatif. Di zaman sekarang sekolah-sekolah jarang menerapkan nilai-nilai luhur Pancasila terhadap para siswanya. endidikan karakter sendiri merupakan pendidikan yang dimana menanamkan nilai serta karakter kepada setiap warga sekolah yang meliputi komponen pengetahuan, kesadaran atau kemauan, dan tindakan untuk melaksanakan nilai-nilai tersebut, baik terhadap Tuhan Yang Maha Esa (YME), diri sendiri, sesama, lingkungan, maupun kebangsaan sehingga menjadi manusia yang berkualitas akhlaknya.

$$
\text { Pendidikan karakter yang }
$$

menyeluruh menitikberatkan pada pendidikan yang tidak hanya menjadikan setiap anak didiknya menjadi manusia yang cerdas serta berprestasi akan tetapi menjadikan mereka sebagai pelaku baik bagi perubahan dalam hidupnya sendiri, yang pada gilirannya akan menyumbangkan perubahan dalam tatanan sosial kemasyarakatan menjadi lebih adil, baik, dan manusiawi.

Dalam lembaga pendidikan yaitu sekolah, memiliki peran aktif untuk membentuk peserta didik dengan pendidikan yang berlabel karakter. Pendidikan karakter di sekolah sendiri merupakan sistem penanaman berupa komponen pengetahuan, kesadaran atau kemauan, dan tindakan untuk melaksanakan nilai-nilai tersebut. Di samping itu, pendidikan karakter dimaknai sebagai suatu perilaku warga sekolah yang dalam menyelenggarakan pendidikan harus berkarakter. Dewasa ini banyak pihak menuntut peningkatan intensitas dan kualitas pelaksanaan pendidikan karakter pada lembaga pendidikan formal.

Pada kenyataannya contoh yang paling banyak ditemukan adalah guru 
sudah tidak dekat dengan murid begitupun siswa-siswinya yang banyak diantara mereka yang acuh tak acuh terhadap keberadaan guru.halitu sangat jelas mengacu pada sebuah karakter individu yang belum terbentuk. Karakter seorang individu terbentuk sejak dia kecil karena pengaruh genetic dan lingkungan sekitar. Proses pembentukan karakter, baik disadari maupun tidak, akan mempengaruhi cara individu tersebut memandang diri dan lingkungannya dan akan tercermin dalam perilakunya seharihari.

Sekolah sebagai lembaga pendidikan formal adalah salah satu daya yang penting, sambil mengevaluasi tujuan, sangatlah penting untuk menyusun kurikulum yang secara jelas memuai mengenai pendidikan karakter. Namun, semakin padatnya waktu belajar, mendorong siswa menjadi siswa yang giat menggapai cita-citanya. Kegiatan akademik sangat menuntut konsentrasi siswa sehingga porsi untuk kegiatankegiatan sosialnya menjadi semakin sedikit. Dorongan untuk berinteraksi secara sosial menjadi semakin sedikit.padahal hal ini sangat penting dalam pembentukan karakter. Berdasarkan hasil wawancara singkat dengan salah satu siswa SMP, diketahui bahwa siswa tersebut tidak terlalu memikirkan tentang pentingnya berkumpul dengan teman sesama. Siswa tersebut lebih memilih untuk berjalan sendiri dalam mencapai cita-cita atau impiannya.

Menyadari bahwa karakter individu tidak bisa dibentuk hanya melalui satu atau dua kegiatan saja, maka akan disusun rancangan kurikulum pembinaan karakter yang berkesinambungan dan terintegrasi dalam lingkungan sekolah, dimana proses tersebut melibatkan semua yang ada di lingkungan sekolah sehingga dapat merasakan manfaat pembinaan karakter dapat dirasakan semuanya. Juga hal yang dapat dilakukan untuk merealisasikan pendidikan karakter di sekolah yaitu salah satu contoh mulailah dengan mematuhi peraturan yang ada di sekolah, dan sekolah harus menjadikan Pendidikan karakter sebagai sebuah tatanan nilai yang berkembang dengan baik di sekolah yang diwujudkan dalam contoh dan seruan nyata yang dicontohkan oleh tenaga pendidik dan kependidikan di sekolah dalam keseharian kegiatan di sekolah.

\section{METODE PENELITIAN}

Metode penelitian pada artikel ini menggunakan teknik studi literatur yaitu dengan mengumpulkan data-data dari jurnal dan sedikit melakukan wawancara singkat terhadap salah satu siswa SMP. Kemudian pada teknik studi literatur ini tidak mengedepankan penelitian langsung melainkan mengacu pada sumber-sumber yang sudah ada.

\section{HASIL DAN PEMBAHASAN}

Kedudukan karakter dalam perjalanan setiap manusia sangat penting sekali. Nilai-nilai pendidikan karakter perlu dikembangkan di sekolah. nilai ini berlaku universal, karena dapat digunakan oleh seluruh siswa di Indonesia tanpa adanya diskriminasi terhadap pihak-pihak tertentu. Nilai-nilai ini bersumber dari agama, Pancasila, budaya, dan tujuan pendidikan nasional. Adapun penjelasannya adalah sebagai berikut.

1. Agama: masyarakat Indonesia adalah masyarakat beragama. Oleh karena itu, kehidupan individu, masyarakat, dan bangsa selalu didasari pada ajaran agama dan kepercayaannya. Secara politis, kehidupan kenegaraan pun didasari pada nilai-nilai yang berasal dari agama. Atas dasar pertimbangan itu, maka nilai-nilai pendidikan budaya dan karakter bangsa harus didasarkan pada nilai-nilai dan kaidah yang berasal dari agama.

2. Pancasila: negara kesatuan Republik Indonesia ditegakkan atas prinsip-prinsip kehidupan Kebangsaan dan kenegaraan yang disebut Pancasila. Pancasila terdapat pada Pembukaan UUD 1945 dan dijabarkan lebih lanjut dalam pasal-pasal yang terdapat dalam UUD 1945. Artinya, nilai-nilai yang terkandung dalam Pancasila menjadi nilainilai yang mengatur kehidupan politik, hukum, ekonomi, kemasyarakatan, budaya, dan seni. Pendidikan budaya dan karakter 
bangsa bertujuan mempersiapkan siswa menjadi warga negara yang lebih baik, yaitu warga negara yang memiliki kemampuan, kemauan, dan menerapkan nilai nilai Pancasila dalam kehidupannya sebagai warga negara. Bahkan pembentukan karakter sejak dini akan sangat menentukan bagaimana seseorang dalam menjalani hidupnya. Siapapun dia, apapun profesinya, ketika memiliki karakter positif, tentu akan lebih baik daripada yang tidak memiliki karakter. Seperti kita ketahui bersama bahwa yang sering menjadi masalah masalah bangsa Indonesia ini adalah banyaknya manusia yang tidak memiliki karakter positif sehingga dimanapun mereka berada akan selalu menimbulkan masalah dan karena hal itu pendidikan karakter sangat diperlukan penerapannya melalui pendidikan formal misalnya.

Pendidikan karakter mengajarkan kebiasaan cara berpikir dan perilaku yang membantu individu untuk hidup dan bekerja bersama sebagai keluarga, masyarakat, dan bernegara, dan membantu mereka untuk membuat keputusan yang dapat dipertanggungjawabkan. Karakter yang menjadi acuan seperti yang terdapat dalam The Six Pillars of Character yang dikeluarkan oleh Character Counts! Coalition. Enam jenis karakter yang dimaksud adalah pertama adalah Trustworthiness, bentuk karakter yang membuat seseorang menjadi berintegritas, jujur, dan loyal. Kedua, Fairness, bentuk karakter yang membuata seseorang memiliki pemikiran yang terbuka serta tidak suka memanfaatkan orang lain. Ketiga, Caring, bentuk karakter yang membuat seseorang memiliki sikap peduli dan perhatian terhadap orang lain maupun kondisi sosial lingkungan sekitar. Keempat yaitu Respect, bentuk karakter yang membuat seseorang selalu menghargai dan menghormati orang lain. Kelima Citizenship, bentuk karakter yang membuat sesorang sadar hukum dan peraturan serta peduli terhadp lingkungan alam sekitar. Terakhir yaitu Responsibility, bentuk karakter yang membuat seseorang bertanggung jawab, disiplin, dan selalu melakukan sesuatu dengan sebaik mungkin.

Sumber yang ada menunjukkan bahwa pendidikan karakter di beberapa Negara dimulai sejak dini, seperti negara Cina. Ada bukti implementasi pendidikan karakter yang tersusun secara sistematis betul-betul memberi efek positif terhadap akademik anak atau siswa. Berikut saya tulis sedikit abstrak pendidikan karakter di negara Cina. Di negara Cina, dalam reformasi pendidikan yang diinginkan oleh Deng Xiaoping pada tahun 1985, secara eksplisit dibuktikan betapa pentingnya pendidikan karakter, Throughout the reform of education system, it is imperative to bear in mind that reform is for the fundamental purpose of turning every citizen into a man or woman of character and cultivating more constructive members of society (Li,2005). Karena itu program pendidikan karakter telah menjadi kegiatan yang menonjol di Cina yang dijalankan sejak jenjang prasekolah sampai universitas. Li Lanqing, seorang politikus dan birokrat Cina yang mempunyai pemahaman yang komprehensif dan mendalam tentang pendidikan menekankan tentang bahayanya sistem pendidikan yang terlalu menekankan hafalan, dan cara mengajar guru yang kaku, termasuk sistem pendidikan yang berorientasi hanya untuk lulus dalam ujian. Sebagai hasilnya, Cina yang relative baru bangkit dari keterpurukan ekonomi, social, dan budaya akibat Revolusi kebudayaan yang dijalankan oleh Mao, bisa begitu cepat mengejar ketertinggalannya dan menjadi negara yang maju.

Perancangan proses pendidikan karakter di Sekolah Menengah Pertama selama ini belum banyak menyentuh pembinaaan karakter siswa dan belum betul-betul mendapat tempat dibandingkan dengan pendidikan akademik, Pendidikan karakter di sekolah juga didefinisikan sebagai pembelajaran yang mengarah pada penguatan dan pengembangan perilaku anak secara utuh yang didasarkan pada suatu nilai tertentu yang dirujuk oleh sekolah di sekolah hanya ada bimbingan konseling yang kurang jelas tujuannya. Masih banyak sekolah yang walau 
menyadari bahwa karakter itu penting, belum melakukan pembinaan serius untuk mengembangkan karakter yang posistif. Hal ini mengakibatkan input yang diterima perguruan tinggi bukanlah mahasiswa yang yang sudah siap untuk dididik karakternya. Berdasarkan hasil wawancara singkat dengan salah satu siswa SMP yang terlihat tidak senang bersosial. Disitu saya dapat mengetahui suatu hal, dimana siswa tersebut hanya ingin memiliki prestasi yang mentereng dengan giat melatih kemampuannya tanpa merisaukan kebutuhan sosialnya yaitu berinteraksi antar sesama.

Pendidikan karakter dapat diintegrasikan dalam pembelajaran pada setiap mata pelajaran. Materi pembelajaran yang berkaitan dengan norma atau nilainilai pada setiap mata pelajaran perlu dikembangkan, dieksplisitkan, dikaitkan dengan konteks kehidupan sehari-hari. Dengan demikian, pembelajaran nilai-nilai karakter tidak hanya pada tataran kognitif, tetapi menyentuh pada internalisasi, dan pengamalan nyata dalam kehidupan peserta didik sehari-hari di masyarakat.

Disana peran seorang guru sangatlah penting untuk mengajarkan betapa pentingnya hidup bersosial. Karakter siswa dapat dibentuk melalui pengajaran oleh gur dengan bebrapa cara seperti memberikan nasihat ataupun motivasi agar siswa tidak mementingkan hal pribadinya, lebih diutamakan interaksi sosialnya. Di sekolah, pendidikan karakter bisa diterapkan oleh guru dan juga oleh individu dewasa yang juga berada di lingkungan sekolah tersebut yang tidak hanya diajarkan di dalam kelas, namun sewaktu istirahat para siswa juga mendapatkan pendidikan karakter missal dari pembantu sekolah, penjaga kantin, dan lain-lain. Caranya mungkin melalui tutur bicara yang sopan, dituntut untuk menghormati orang yang lebih tua. Hal ini bertujuan agar siswa setelah lulus Sekolah Menengah Pertama siap menghadapi kehidupan di masa dewasa dimana karakter saangat berperan penting dalam mengarungi perjalanan hidup selanjutnya.

Secara umum, rencana pengembangan karakter dapat dibagi menjadi tiga tahap, pertama, tahap awal. Pengembangan karakter menekankan pada kesadaran dan perubahan sikap siswa dari awalnya tidak terlalu menghormati orang yang lebih tua menjadi lebih menghormati. Kedua tahap madya, yaitu tahapan yang menekankan pada proses belajar dan bersosialisasi dengan orang lain dan mengembangkan kepekaan mereka. Ketiga, tahap akhir, tahap ini memfokuskan pada sifat siswa setelah lulus dari ssekolah terebut. Baik tahap awal, madya, maupun tahap akhir, pengembangan karakter yang dilakukan senantiasa mengacu pada enam karakter yang telah disebutkan sebelumnya.

Thomas Lickona memberikan catatan bahwa ada enam unsur yang sangat penting dalam usaha menciptakan budaya moral yang baik di sekolah.[7] Enam unsur tersebut adalah:

a. Kepemimpinan moral dan akademis dari kepala sekolah

b. Disiplin dalam seluruh lingkungan sekolah yang memberi teladan, mendorong, dan menjunjung tinggi nilai-nilai moral

c. Kesadaran komunitas di seluruh lingkungan sekolah

d. Organisasi siswa yang melibatkan para siswa dalam mengurus diri sendiri dan menumbuhkan perasaan handarbeni terhadap sekolah

e. Sebuah atmosfer moral yang di dalamnya terdapat sikap saling menghormati, keadilan, dan kerja sama yang terwujud dalam semua bentuk hubungan antar individu.

f. Menjunjung arti penting moralitas dengan memberi waktu khusus untuk penanganan masalah moral.

Sasaran pendidikan karakter adalah semua warga sekolah, meliputi para peserta didik, guru, karyawan administrasi, dan pimpinan sekolah. Melalui program ini diharapkan lulusan memiliki keimanan dan ketaqwaan kepada Tuhan Yang Maha Esa, berakhlak mulia, berkarakter mulia, kompetensi akademik yang utuh dan terpadu, sekaligus memiliki kepribadian yang baik sesuai norma-norma dan budaya 
Indonesia. Pada tataran yang lebih luas, pendidikan karakter nantinya diharapkan dapat menjadi budaya sekolah. Kriteria pencapaian pendidikan karakter adalah terbentuknya budaya sekolah, yaitu perilaku, tradisi, kebiasaan keseharian, dan simbolsimbol yang dipraktikkan oleh semua warga sekolah, dan masyarakat sekitar sekolah harus berlandaskan nilai-nilai tersebut.

\section{KESIMPULAN}

Pendidikan karakter sangat penting bagi pertumbuhan individu menjadi manusia yang seutuhnya dan sebaiknya dilakukan mulai sejak dini. karena karakter individu tersebut akan menjadi penopang untuk mengarungi perjalanan hidup yang berat. Di Sekolah Menengah Pertama karakter siswa kebanyakan masih belum terbentuk, banyak penyimpangan yang dilakukan siswa juga sebab dari guru yang kurang perhatian dan kurang memahami pembentukan karakter. Sehingga dengan adanya artikel ini diharapkan semua guru dan instansi sekolah bisa menerapkan Pendidikan karakter untuk siswa-siswinya agar jika sudah lulus mereka tidak terkejut menghadapi hal baru dan siswa-siswi sudah tertanam moral yang baik dalam terjun ke masyarakat.

Pada intinya pendidikan karakter sangat-sangatlah penting diterapkan lembaga pendidikan formal seperti Sekolah Menengah Pertama, bukan hanya untuk siswa saja, pendidikan karakter yang diajarkan oleh seseorang yang lebih dewasa juga bisa sebagai pembelajaran bagi orang yang mengajarkan tersebut untuk menjadi sebuah dorongan untuk melakukan kegiatan positif. Tujuan pendidikan karakter adalah meningkatkan mutu penyelenggaraan dan hasil pendidikan di sekolah yang mengarah pada pencapaian pembentukan karakter dan akhlak mulia peserta didik secara utuh, terpadu, dan seimbang, sesuai standar kompetensi lulusan. Pendidikan karakter dalam lingkup nasional dilakukan dalam rangka mengembangkan potensi peserta didik agar menjadi manusia yang beriman dan bertakwa kepada Tuhan Yang Maha Esa, berakhlak mulia, sehat, berilmu, cakap, kreatif, mandiri, dan menjadi warga negara yang demokratis serta bertanggung jawab.

\section{DAFTAR PUSTAKA}

Furqon Hidayatullah, 2010. Pendidikan Karakter: Membangun Peradaban Bangsa. Yusma

Hurlock, EB. 2004. Psikologi Perkembangan. Erlangga: Jakarta.

Li, L., 2005. Education for 1.3 Billion. Pearson Education and China: Foreign Language Pustaka: Surakarta. Rismayanti \& Rolina, 2004. "Pencarian Jati Diri Melalui Proses belajar dan Pengalaman". SPS Teaching \& Research Press. UGM: Yogyakarta. 